\title{
ДОКТРИНА КАК ИСТОЧНИК МЕЖДУНАРОДНОГО ПРАВА (НАУЧНЫЙ ПОДХОД НЕМЕЦКИХ ЮРИСТОВ)
}

\begin{abstract}
Аннотация: В статье исследуются вопросы, связанные с подходом немецких юристов кдоктрине, как к одному из источников международного права.В немецкой правовой системе доктрина не признаётся формальньл источником права, но рассматривается как реально существующий и оказывающий фактическое влияние на право вспомогательный источник.Влияние доктрин наиболее выдающихся учёных на создание норм международного права осуществляется различными способами и проявляется в решениях международного суда как средства мирного разрешения споров, при подписании международных договоров, в исключительных ситуацчиях, выходящуих из общепринятых представлений о проиессе создания таких норм, а таже в односторонних заявлениях глав государств. Автор соотносит юридические, идеологические и политические аспекты доктрины. Рассматривает эволюичию этого источника права на основе научных работ немецяих юристов XVII-XIX вв. Анализирует такие доктрины как «внешнего государственного права», «о вечном мире», «возникновения международно-правовых обязательств из деликтов» и др. Вывод к которому приходит автор состоит в том, что в современное международное право характеризуется созданием большого количества доктрин и комментариев, с изелью установления общзезначимых норм международного права и как следствие - увеличением количества противоречий в системе международно-правовых норм. Учитывая, что каждый из комментаторов (сознательно или бессознательно) отстаивает мнения, выгодные его государству или политическому руководству,
\end{abstract} роль доктрины постепенно утрачивается.

Review: The article is devoted to the study of the issues regarding the approach of German lawyers to doctrine as one of the sources of international law. The German legal system does not recognize doctrine as a formal source of law, but it is recognized as a existing accessorial source of law, which possesses de facto influence on it. The influence of doctrines of the most highly regarded scholars on the formation of the norms of international law may be implemented in various ways, and it may be reflected in the decisions of international court as means of peaceful resolution of disputes, in signing of international treaties, and in exceptional circumstances based upon the generally accepted positions on the formation of such norms, as well as in unilateral statements of heads of the state. The author correlates legal, ideological and political aspects of doctrine. He studies evolution of this source of law based upon scientific works of German lawyers of XVII - XIX centuries. He analyzes the doctrines of "external state law", "eternal peace”, "formation of international legal obligations out of wrongful acts", etc. The author concludes that the modern international law may be characterized by formation of a large number of doctrines and interpretations in order to establish the generally valid norms of international law, and the growing number of contradictions in the international legal norms is what follows from it. Taking into account that each of those persons interpreting the norms (consciously or unconsciously) supports the position, which is profitable for his state or political government, the role of doctrine is being forfeited. Ключевые слова: Германия, немеикая концепиия, вечный мир, внешнее государственное право, доктрина, идеология, право, политика, источник права, реализм

Keywords: Germany, German concept, eternal peace, external state law, doctrine, ideology, law, politics, source of law, realism.

П роцесс формирования международного права в самостоятельную систему права был обусловлен с одной стороны, образованием государств, а соответственно - возникновением потребности урегулирования отношений между ними, а с другой - отсутствием международного правосознания и механизма создания правовых норм, регулирующих международные правоотношения.Сильное влияние на создание системы международного права, особенно на первом этапе его развития, оказали труды учёных естественно-правового направления. Представителями этой школы в Германии являются С. Пуфендорф, Х. Томазий, Х. Вольф, Э. де Ваттель. Их гуманистические устремления, сравнимые с философским утопизмом не соответствовали ценностям политиков и идеалам буржуазии. Но, тем не менее, доктрины христианских философов составили основу международного права, которое часто называли «профессорским правом» и способствовали формированию международного правосознания.Если в XVI-XVII в.в. положения доктрин редко применялись при заключении международных договоров, то при разрешении 


\section{Право и политика $8(164) \cdot 2013$}

споров часто цитировались в судах. К середине XVII в. международное право приобрело контуры системы права, со своими субъектами, объектом и системой источников.В отличие от внутригосударственного права, международное право не имеет конституционных норм и специальных актов в привязке к компетенции принимающих их органов государства.Субъекты международного права сами, согласуя свои интересы, определяют не только содержание международно-правовых норм, но и внешнюю форму их существования.Нормы права п.1 ст. 38 Статута Международного Суда ООН устанавливают следующие источники международного права: международный договор, международный обычай, общие принципы права. Судебные решения (Gerichtsentscheidungen) и доктрины (Lehrmeinungen), как следует из этой же статьи (с оговоркой, указанной в статье 59 Статута Международного Суда ООН), рассматриваются как вспомогательное средство для установления норм права.В немецкой правовой системе доктрина не признаётся формальным источником права, но рассматривается как реально существующий и оказывающий фактическое влияние на право вспомогательный источник.Под доктриной, как источником права, понимается наука (теория, концепция, идея), которая во всех, без исключения случаях используется в законодательном и правотворческом процессе. «Доктрина» - (лат. doctrina - учение, наука) означает «совокупность признанных научных или официальных взглядов на цели, задачи, принциипы и основные направления чего-либо».В течение длительного времени в Германии она представляла один из основных источников права, которое было выработано в университетах в период XVII-XIX вв..Догматизм любой доктрины проявляется в её идеологической и политической направленности. Именно с этих позиций составители Дипломатического словаря, характеризуют внешнеполитическую доктрину государства. К этому виду относятся доктрины: Монро (1823 г.), Стимсона (1931 г.), Трумэна (1947 г.), Хальштейна (1956 г.) и др., основополагающие идеи которых периодически находят своё выражение в практике международных отношений.

К числу наиболее известных доктрин международного права относятся доктрины:

- «о праве справедливой войны» (Г. Гроций 1625 г.);

- «о вечном мире» (И. Кант - 1795 г.);- «внешнего государственного права» (Г.В.Ф. Гегель - 1821 г.), «господства права» Rule of Law (первая половина XIX в), «реализма» (Р. фон Иеринг - вторая половина XIX в.), признания государств (Р. фон Иеринг, А. Лассон, Ф. Цорн — вторая половина XIX в.);- «мирового вселенского права» (Э. Ламбер и Р. Солейм - 1900 г.), «возникновения международно-правовой ответственности из деликтов (А.В. Гефтер - 1904 г.) и др.Необходимость использова- ния мнений учёных для развития юридической науки, как считал в 1828 г. представитель немецкой школы международного права Пухта Г.Ф. (1798-1846), обусловлена двумя обстоятельствами. С одной стороны - юристы «как представители народа» выражают господствующие правовые убеждения, а с другой — выявляют из системы права и формулируют определенные идеи и принципы.В немецкой национальной системе права доктрина имела первостепенное значение с националистическим оттенком. Сложившаяся ситуация объяснялась следующими причинами:- во-первых, нормы международного права с трудом утверждались в практику международных отношений;- во-вторых, формирование понятия международного права как самостоятельной отрасли права утверждалось в общественном сознании длительное время.Именно в силу этих причин в Германии в конце XVIII в. возникли нигилистические концепции международного права. Они имели смешанные направления, основанные на естественно-правовом и позитивно-правовом подходах.Первое направление выражалось в доктрине «внешнего государственного права», сформулированной немецким философом Г. Гегелем. Она содержала идею относительно обязательной силы международного права, т.е. государство само создаёт и отменяет нормы права в своих отношениях с другими государствами. Оправдывая «нравственный момент войны», он отмечал, что война как внешнее поведение государства коренится в его внутренней сущности, в принципах и нуждах его внутренней организации. Гарантом же независимости государства выступают его вооружённые силы, с помощью которых оно обеспечивает свой внешний суверенитет. Не отрицая принцип международного права, а следовательно, возможность правовых отношений государств, Гегель исходил из того, что государства находятся в отношениях друг к другу в естественном состоянии, и действительность их прав коренится и обнаруживается не во власти возвышающегося над ними всеобщего международного права, а в их особенной суверенной воле.Не менее значимая фигура интеллектуальной мысли Германии - И. Кант - тоже не признавал международное право, обозначая его «правом государств по отношению друг к другу (ius publikum civitatum)». Эта позиция была характерной для научных взглядов того исторического периода. Аргументация учёного, состояла в том, что «международное право строится на договорах, содержащих уже в самом акте их заключения скрытую предпосылку нарушения договорных обязательств». Несмотря на противоречия этого постулата, И. Кант сформулировал свою знаменитую доктрину «о вечном мире», в основе которой лежала идея морального долженствования.Практика международных отношений первой половины XIX в. способствовала разработке нового направления нигили- 
стической концепции международного права, более известного как доктрина автолимитации, т.е. самоограничения государства. Её сущность состояла в том, что соблюдение международно-правовых норм зависит от воли государств, которая может изменяться. А значит - международное право не имеет юридической силы и может рассматриваться только как «позитивная мораль». Но уже в начале XX в. ординарный профессор Академии консульской службы и сотрудник Министерства иностранных дел Австрии А. Фердросс опровергая эти идеи, обосновал тезис: «Доктрина юридического позитивизма не зависит от норм морали».Во второй половине XIX в. широкое распространение в Европе получила доктрина «реализма». Известный немецкий юрист Р. фон Иеринг выразил её содержание в формуле: «право - это политика силы». Идеи этого учения были развиты в трудах авторитетных учёных Германии (Р.Мооль, А.В.Гефтер, А. Лассон, А. Меркель, Ф. Цорн и др.). Особой популярностью его основные положения пользовались во второй половине XX в. у немецких юристов периода националсоциалистической диктатуры (Л. Шехер, Г. Николаи, Г. Крауз и др.). И только с победой демократических идей и кодификации, доктрина уступила место закону.В правовой системе ФРГ доктрина является вспомогательным источником права. Её роль, как источника права, проявляется в том, что именно она создаёт словарь юридических (правовых) понятий, которыми пользуется законодатель; содержит закономерности, с помощью которых законодатель находит право, закрепляет его в определённых источниках и толкует нормативно-правовые акты. В указанных процессах доктрина оказывает влияние, прежде всего, на законодателя, его сознание и волю. Воспринимая содержащиеся в ней положения в виде тенденций и закономерностей, он принимает соответствующие решения. Она позволяет ориентировать юридическую деятельность на прогрессивное развитие права и государства, т.е. на истинную необходимость. Оказывая влияние на законодателя, доктрина выступает как косвенный источник права. Когда же законодатель фиксирует в нормах права достижения науки, можно говорить о прямом её воздействии на принятие закона. Анализ Основного Закона ФРГ свидетельствует о том, что доктрина естественного права послужила одним из его источников. Так, например, среди составляющих фундаментальные основы конституционного строя ФРГ является институт основных прав и свобод человека и гражданина, содержащийся в первой главе этого закона (ст.ст. ст. 1-19).Основные положения концепции немецкого исследователя Г. Геллера явились предметом дискуссий о перспективах государственности Германии и оказали большое влияние на правовые положения Основного закона ФРГ (1949 г.). Другой пример - Хартия Европейского Союза об основных правах от 07.12.2000, источником которой была доктрина известного немецкого юриста и государственного деятеля Р. Херцога.Автором доктрины возникновения международно-правовых обязательств из деликтов был представитель научной школы юридического позитивизма А.В. Гефтер, который отмечал, что международное право не знает преступления в том виде, каким оно представлено в национальном праве. Немецкий исследователь полагал, что в международном праве существует научное понятие «правонарушение». А каждое правонарушение обязывает правонарушителя возместить потерпевшому ущерб, поскольку всегда, когда в результате произвола причинено ущемление (Ungleichheit), должно иметь место устранение этого нарушения. Это закон справедливости (Gerechtigkeit).Ставя в заслугу A.В. Гефтеру создание доктрины возникновения международно-правовых обязательств из деликтов, профессор Санкт-Петербургского императорского университета Ф.Ф. Мартенс, указывал, что «теория Гефтера в этом вопросе страдает только тем недостатком, что смешивает право гражданское с международHblм».Влияние доктрин наиболее выдающихся учёных на создание норм международного права осуществляется различными способами и проявляется в решениях международного суда как средства мирного разрешения споров, при подписании международных договоров, в исключительных ситуациях, выходящих из общепринятых представлений о процессе создания таких норм, а таже в односторонних заявлениях глав государств.Теоретические исследования правовой природы доктрины как источника международного права позволяют установить закономерности ее возникновения и тенденции развития. Интерес, который проявляли к ней немецкие юристы ещё в XIX в., продолжает волновать научную мысль и в XXI в. Всё чаще высказываются предложения о пересмотре «перечня», источников международного права, содержащегося в п.1 ст. 38 Статута Международного Суда ООН. Предложения учёных обусловлены следующими обстоятельствами:а) неопределённостью положений международного права, которые не всегда получают законченное юридическое оформление в соглашениях общего характера и в международных договорах; б) застойностью как свойством любой отрасли права; в) созданием большого количества доктрин и комментариев, с целью установления общезначимых норм международного права и как следствие - увеличением количества противоречий в системе международноправовых норм. Учитывая, что каждый из комментаторов (сознательно или бессознательно) отстаивает мнения, выгодные его государству или политическому руководству, роль доктрины постепенно утрачивается. 


\section{Право и политика $8(164) \cdot 2013$}

\section{Библиография:}

1. Лукашук И.И. Международное право: наука и практика // Межд. публ. и частное право. — 2003. — № 2 (11);

2. Кант И. К вечному миру // Трактаты о вечном мире. Сб. произведений / Сост. И.С. Андрееваи А.В. Гулыга. - СПб., 2003;

3. Triepel H. Völkerrecht und Landesrecht. Leipzig. Vrlg. von C.L. Hirschfeld. 1899;

4. Каламкарян Р.А. Роль доктрин наиболее квалифицированных специалистов по публичному праву различных наций в формировании современного международного права // Государство и право. 2006. — № 6;

5. Гулыга А.В. Немецкая классическая философия. 2-е изд., испр. и доп. - М.: «Рольф», 2001 ;

6. Гулыга А.В. Кант. - 4-е изд., испр. и доп. - М.: «Молодая гвардия», 2005;

7. Петрученко О. Латинско-русский словарь. Репринт IX - го издания 1914. - М.: 1994;

8. Энциклопедический словарь. Т. $\mathrm{X}$ «А» (Десмургия - Домиціанъ). - СПб.: изд. Ф.А. Брокгаузъ, И.А. Ефрон. 1893;

9. Антонов И.П. Особенности и соотношение категорий «концепция» и «доктрина» в науке международного права // Евразийский юридический журнал № 3 (10), 2009;

10. Юридическая энциклопедия. Изд-е 5-е, доп. и перераб. / Под ред. М.Ю. Тихомирова - М., 2001;

11. Гегель Г. В.Ф. Философия права. - M., 2007;

12. Heffter A.W. Das europäische Völkerrecht der Gegenwart, 7. Aufl. - Berlin, 1881.§ 32;

13. Антонов И.П. Основные проблемы немецкой концепции международного права. - М.: Изд-во РУДН. 2007;

14. Мартенс Ф.Ф. Современное международное право цивилизованных народов. Т. І. Изд-е V. — СПб., 1909;
15. Нерсесянц В.С. Философия права Гегеля. - М., 1992.

\section{References (transliteration):}

1. Lukashuk I.I. Mezhdunarodnoe pravo: nauka i praktika // Mezhd. publ. i chastnoe pravo. — 2003. — № 2 (11);

2. Kant I. K vechnomu miru // Traktaty o vechnom mire. Sb. proizvedeniy / Sost. I.S. Andreevai A.V. Gulyga. — SPb., 2003;

3. Triepel H. Völkerrecht und Landesrecht. Leipzig. Vrlg. von C.L. Hirschfeld. 1899;

4. Kalamkaryan R.A. Rol' doktrin naibolee kvalificirovannyh specialistov po publichnomu pravu razlichnyh naciy $\mathrm{v}$ formirovanii sovremennogo mezhdunarodnogo prava // Gosudarstvo i pravo. — 2006. — № 6;

5. Gulyga A.V.Nemeckaya klassicheskaya filosofiya. - 2-eizd., ispr. i dop. - M.: «Rol'f», 2001 ;

6. Gulyga A.V. Kant. - 4-e izd., ispr. i dop. - M.: «Molodaya gvardiya», 2005;

7. Petruchenko O. Latinsko-russkiy slovar'. Reprint IX — go izdaniya 1914. — M.: 1994;

8. Enciklopedicheskiy slovar'. T. X «A» (Desmurgiya Domician'). — SPb.: izd. F.A. Brokgauz', I.A. Efron. 1893;

9. Antonov I.P. Osobennosti i sootnoshenie kategoriy «koncepciya» $\mathrm{i}$ «doktrina» v nauke mezhdunarodnogo prava // Evraziyskiy yuridicheskiy zhurnal № 3 (10), 2009;

10. Yuridicheskaya enciklopediya. Izd-e 5-e, dop. i pererab. / Pod red. M.Yu. Tihomirova - M., 2001;

11. Gegel' G. V.F. Filosofiya prava. - M., 2007;

12. Heffter A.W. Das europäische Völkerrecht der Gegenwart, 7. Aufl. - Berlin, 1881.§ 32;

13. Antonov I.P. Osnovnye problemy nemeckoy koncepcii mezhdunarodnogo prava. - M.: Izd-vo RUDN. 2007;

14. Martens F.F. Sovremennoe mezhdunarodnoe pravo civilizovannyh narodov. T. I. Izd-e V. — SPb., 1909;

15. Nersesyanc V.S. Filosofiya prava Gegelya. — M., 1992. 